\title{
Si 脱酸反応機構と冷却凝固過程における
}

$\mathrm{SiO}_{2}$ 介在物の生成についで

\author{
坂上 六 郎**. 笹 井 興 士***

\section{On the Deoxidation of Liquid Iron with Silicon and the Formation of $\mathrm{SiO}_{2}$ Inclusions during Solidification}

Rokuro SAKAGAMI and Takashi SASAI

Synopsis:

The mechanism of the deoxidation of liquid iron with $\mathrm{Si}$ and the formation of $\mathrm{SiO}_{2}$ inclusions during solidification were studied on the basis of the various facts.

The conclusions obtained were as follows.

1) The deoxidation reaction is not completed immediately after addition of $\mathrm{Si}$ and the supersaturation in liquid iron continues for several minutes.

2) The $\mathrm{SiO}_{2}$ particle does not grow by the collision and coalescence with other particles, but grows principally by the diffusion of the solute atoms in the melt.

3) The growth of $\mathrm{SiO}_{2}$ particle is controlled by the interfacial reaction.

4) The progress of the interfacial reaction is represented by the following equation.

$$
\mathrm{SiO}_{2}+\mathrm{O}(\mathrm{abs})=\underline{\mathrm{Si}}+2 \underline{\mathrm{O}}+\mathrm{O}(\mathrm{ads})
$$

5) The process of the deoxidation with $\mathrm{Si}$ should be discussed taking account of the isolation of the $\mathrm{SiO}_{2}$ inclusion from the melt and the decrease of the concentration of the dissolved oxygen.

6) The process of the deoxidation and the formation of $\mathrm{SiO}_{2}$ inclusions during solidification are definitely influenced by nucleation and growth.

(Rec $\in$ ived Mar. 5, 1971)

\section{1. 緒}

\section{言}

著者らはこの数年間 $\mathrm{Si}$ 脱酸反応の機構を解明するた めに種々の実験を行ない, $\mathrm{SiO}_{2}$ の核生成と成長につい て多くの興味ある事実を明らかにしてきたが1，これら のすべてが解明されているわけではなく, Si 脱酸機構の 全貌を理解するには，なお不明の点がいくつか残されて いる.

このため現在さらに研究を続行中であるが, 今回はこ れをでの成果を中心にして, Si 脱酸反応機構および凝固 過程における $\mathrm{SiO}_{2}$ 介在物生成を解説的に説明し, これ に関する問題点を提起してみたい。

\section{2. 実 験 方 法}

\section{$2 \cdot 1$ A 実験}

やく $450 \mathrm{~g}$ の電解鉄を種々の材質の坩堝中で溶解し, A気流下で一定温度に保持してから, 所定の金属 $\mathrm{Si}$
とりつけた石英管を溶鉄に浸漬し， $2 ， 3 \mathrm{sec}$ 掜拌する. 以後時間ごとにサンプリングを行ない，採取試料の $\mathrm{Si}$, 酸素值の变化および抽出介在物の顕微鏡観察から脱酸反 応の進行を追求した.

\section{$2 \cdot 2$ B 実験}

先端から $60 \mathrm{~mm}$ の高さに小孔をあけた石英管に所定 量の $\mathrm{Si}$ を装入しておき, $\mathrm{A}$ 気流下でこれを溶鉄中に $30 \mathrm{~mm}$ 程度浸漬し，Si の溶融したところでさらに浸漬 して小孔よりやく $20 \mathrm{~g}$ の溶鉄を採取する. 採取直後お よび $30 \mathrm{~mm}$ の位置にもどして一定時間保持してから水 中急冷した，溶解にはタンマン炬を使用した。

\section{$2 \cdot 3 \mathrm{C}$ 実験}

所定量の $\mathrm{Si}$ を含む $\mathrm{SiO}_{2}$ 坩佩中の溶鉄を, $1550^{\circ} \mathrm{C}$ に やく $1 \mathrm{hr}$ 保持してから, 温度を急激に $1600^{\circ} \mathrm{C}$ あるい

* 昭和 46 年 3 月 5 日受付

** 東北大学金属材料研究所工博

*** 東北大学金属材料研究所 


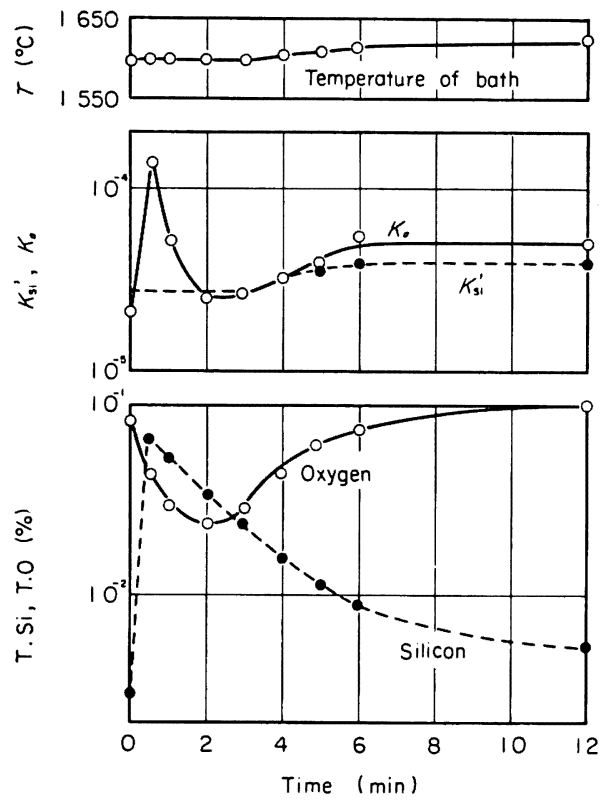

Fig. 1. Progress of the deoxidation after addition of $0.15 \% \mathrm{Si}$ in a $4-\mathrm{kg}$ silica crucible at $1600^{\circ} \mathrm{C}$ (Fischer and Wahlster).

は $1635^{\circ} \mathrm{C}$ にあげる.これらの温度に到達してから以後 サンプリングを開始し， $\mathrm{SiO}_{2}$ 溶解反応の進行にともな う溶鉄 $\mathrm{Si}$ および酸素変化を追跡した，A， C実験では 高周波炉を使用した。

\section{3. 実験結果と考察}

\subsection{FISCHER らの実験 2 )}

FISCHER らは Si 脱酸後採取した試料の全酸素㧍よび 全 $\mathrm{Si}$ 濃度から見かけの溶解度積 $K_{a}=[\% \mathrm{~T} . \mathrm{Si}][\% \mathrm{~T}$. $\mathrm{O}^{2}$ の時間変化をプロットし, これが平衡の溶解度積 $K^{\prime}{ }_{\mathrm{Si}}$ と一致した時点で生成した $\mathrm{SiO}_{2}$ 介在物は浮上し終 わつたと考え，この手法にもとづいて， $\mathrm{SiO}_{2}$ 介在物の 浮上におよぼす $\mathrm{Si}$ 添加量, 溶解温度, 坩佩材質の影響 などを論じている. (Fig. 1)

$\mathrm{SiO}_{2}$ 坩堝中の実験で， $K_{a}$ が $K^{\prime}{ }_{\mathrm{Si}}$ に一致したところ でほほ平衡状態に到達したとみなすここには問題がない としても，これを $\mathrm{SiO}_{2}$ 介在物の分離終了時点とみなす ところに，一つの前提が含まれている.

すなわち, $\mathrm{Si}$ 脱酸後の溶解酸素変化が不明の現在, 極 端な場合として, Fig. 1 の Si, 酸秦曲線をそれぞれ溶解 $\mathrm{Si}$ ，溶解酸祘曲線と考えることも可能なはずであり，単 純に $K_{a}$ が $K^{\prime} \mathrm{Si}$ と一致したところで生成した介任物が 浮上を完了したと最初から決わてかかることはできな W.
ところが FISCHER らはこのような見方のあることをま つたく無視し, 脱酸反応は高速反応であり, Si 脱酸の場 合も, $\mathrm{Si}$ 添加直後に $\mathrm{SiO}_{2}$ 介在物の生成は完結してい るであろうという徉来からの漠然とした通説を暗黙の前 提として，Si 脱酸過程を考察しているわけであり，いわ ば片手落ちの議論をしているということができる.

脱陑反応が高速度で進行すると無条件に断定できない 理由としては, 常識的のことながら,つぎの 2 点があげ られる。

\section{1) 反応界面積}

脱酸反応は典型的な界面反応であり，反応の速度は， 亡ず反応界面䅡の大小によつて左右される，ところで界 面秥の大きさは，核生成によつて沈まつてくるが，この 過程の実態がきわめて曖昧であることを考慮すると，脱 酸反応がつ权に反応界面積の大きい状况のもとに進行す ると考えるのは，むしろ危険である。

2) 化学反応速度

高温における界面反応の機構はほとえど解明されてお らず，高温反応期高速反応と断定してよい証拠はない。

化学反応によつて律速されるか，もしくは反応抵抗を 無視しえないような反応系が，近年製鋉反応の場合にも 多数報告されていう点に注目すべきであろう。

このようなここから，脱酸過程を考察するときには， 优隶り通説に上らわれることなく現象を忠実に観察して ゆくことが必要不可欠と考えられる．以下順を追つて実 駼絬策を説明しよう。

\section{$3 \cdot 2 \mathrm{~B}$ 実験における $\mathrm{SiO}_{2}$ 粒子の成長}

Photo. 1 は Si 添加量がやく $0.1,0.35,0.8 \%$ の 3 系列について, 試料採取直後および所定時間保持してか ら水中急泠した試料中に含をれる $\mathrm{SiO}_{2}$ 粒子の成長過程 を電子顕微鏡で観察したものであり，またFig. 2 は Si $0.35 \%$ 添加後の粉子径分布の変化を示した。

これらの結果から明らかなように， $\mathrm{SiO}_{2}$ 粒子は保持 時間とともに次算に成長して河き， $5 \mathrm{~min}$ 後に Si〜0.1 $\%$ の場合は $1 \mu$ ていどからやく $6 \mu, \mathrm{Si} \sim 0.8 \%$ の場 合には $0.5 \mu$ から $4 \mu$ ていどの粒子に成長する.ただ $5 \mathrm{~min}$ 以上保持してもそれ以上の成長は顕著に認められ なかつた。 また同一保持時間では, Si 添加量の多いもの ほど粒子径は小さい。

さて粒子成長の機㩐としては，つぎの 3 種をあげるこ とができる。

1) 小粒子の㠜集

2) オストワルド成長

3) 搪政成長

まず 1）の見方であるが，粒子の㣫突，凝集によつて 


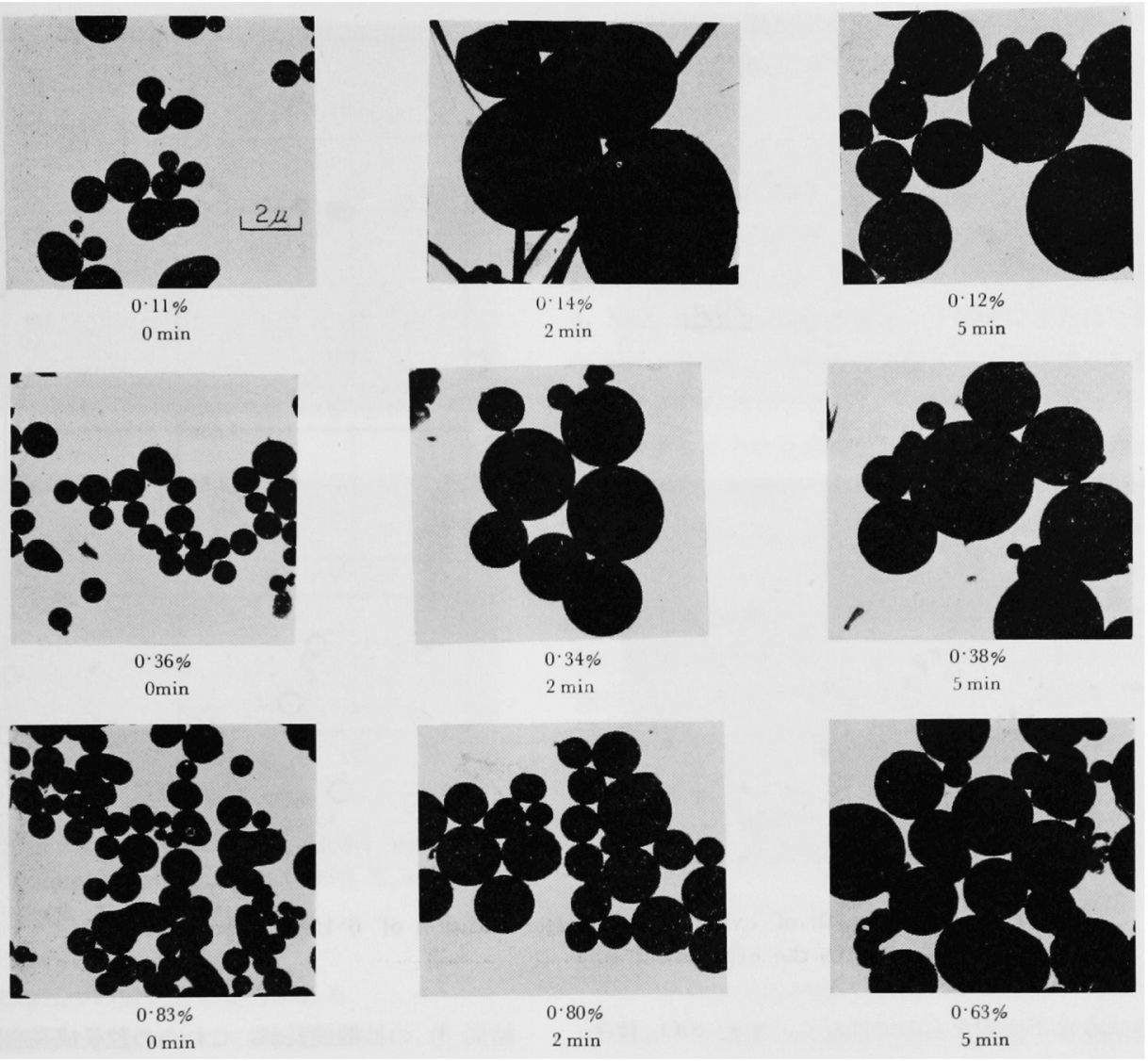

Photo. 1. Growth of $\mathrm{SiO}_{2}$ particles after addition of various amount of silicen in the experiment B.

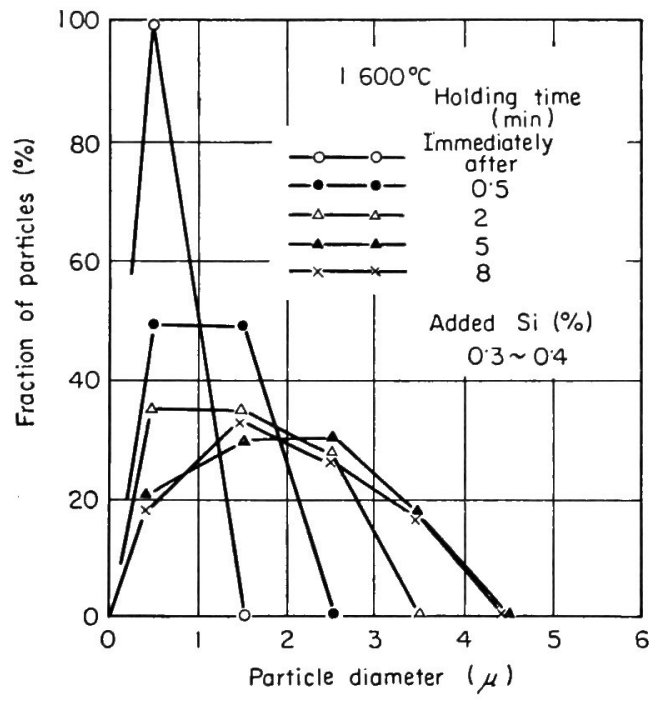

Fig. 2. Size distribution of $\mathrm{SiO}_{2}$ particles at various holding time.
成長が進行するという考え方は，説明困難ないくつかの 事実によつて否定せざるをえない.

たとえば粒子はその大半が球形であり, 小粒子が付着 してできたとみられるような粒子は，小数の漂管形介在 物を別にすれば（この種の介在物も2 個の粒子が付着し たものとは断定できない)，まつたく存在しなかつた。 これに対しては，衝突した瞬間に一体の球形粒子になる という見方から一応反論することはできるが， $\mathrm{SiO}_{2}$ 粒 子の球形一体化はこのように容易に起こるものではな w.

Photo. 2 にB実験で $\mathrm{Si}-\mathrm{Mn}$ 脱酸 $(\mathrm{Si} \sim 0.15 \%, \mathrm{Mn} \sim$ $0.15 \%$ ）したときの粒子成長を示した．脱酸生成物組成 は $\mathrm{MnO}$ 量が $1 \%$ ていどで $\mathrm{SiO}_{2}$ 粒子とみなすことがで き,また成長の挙動も Photo. 1 の場合とほとえど同様 であるが，Si 脱酸のときと異なり，この場合には粒子 のほぼ中心部に $\mathrm{MnO}$ の高い球形の別相が一個存在し ている.このものは脱酸直後の小粒子からすでに粒子の 中心部に存在しており, 保持時間中の成長過程に消滅し 


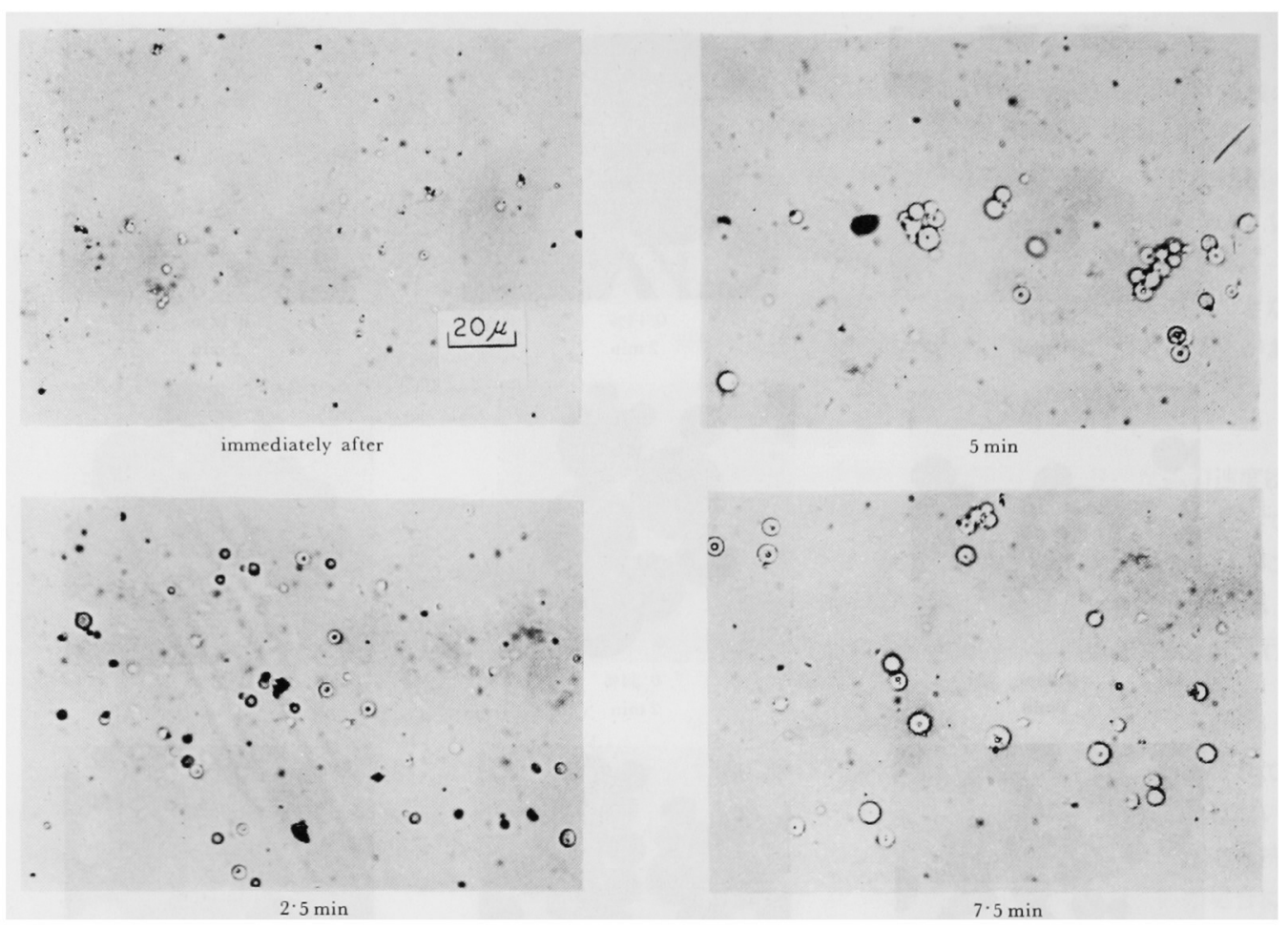

Photo. 2. Growth of oxide particles after addition of $0.15 \% \mathrm{Si}$ and $0 \cdot 15 \%$ $\mathrm{Mn}$ in the experiment $\mathrm{B}$.

てしまうような不安定なものではなく，また $\mathrm{SiO}_{2}$ 粒子 内を自由に動きまわることのできるものでもない，

しゲがつて凝集によつて成長し，そのさい瞬間的に一 体の粒子になるとした場合，成長粒子には中心といわず 粒子内のいたる所にこのような小粒子が多数存在してい なければならないはずである。成長粒子でも，これが中 心部に一個しか認められ就いとと, Photo. 1 やPhoto. 2では，㠜集がまつたく起こつていないことも示したも のと考光られる. また $5 \mathrm{~min}$ 以後は成長が頙著に認め られないことも, 凝集説にとつては致命的である.(Si$\mathrm{Mn}$ 脱酸の詳細は別報に報告)

つ当はオストワルド成長の可能性であるが，前報でも 計算例を示したよらに，この機櫣による精子の成長速度 はかなり遅く，その可能性をまつたく否定することは問 題があるにしても， $5 \mathrm{~min}$ という短時間に $6 \mu$ ていどの 粒子に成長する事実を説明することは困難である。また この機楧による $\mathrm{Al}_{2} \mathrm{O}_{3}$ の成長速度は, $\mathrm{SiO}_{2}$ のそれより はるから淽いはずであるのに， B 実験で $\mathrm{Al}$ 脱酸すると， $\mathrm{Al}_{2} \mathrm{O}_{2}$ のほうが逆に大きく成長する事実も, Photo. 1, 2 の成長がオストワルド成長によるものではないことを 裹付けている.
結局 3) の拡散成長が，これらの粒子成長を説明しう る唯一の機構であると結論される.

さて溶質原子の拡散によつて粒子が 5 min 間も成長 を続けるということは，その間溶鉄中に Si や酸素が過 的和に溶解していたことを意味する。すなわち $\mathrm{Si}$ 脱酸 では, 脱酸後に溶解酸素が平衡值ないし定常値まで急激 に低下するようなことはなく，B実験の脱酸条件では， 少なくとも $5 \mathrm{~min}$ 間は過飽和な状態の保持されること が明らかとなつた。

なを B 実䮖では脱酸添加方法が特殊であるとはい兄， Photo. 1 や Photo. 2 の観察から判断すると, 脱酸直後 はさしろ脱酸反応はほとんど進行していないと考元ざる をえないこの点泣粒子の凝集が実際はきわ的て起こり にくい機構であることとあわせて，認識を改める必要が あると思われる。

\section{$3 \cdot 3$ 溶解酸素変化-粒子成長速度}

脱酸時に尘成した $\mathrm{SiO}_{2}$ 粒子は，過飽和な 溶解酸素 を消費しながら成長してゅくが，溶解酸素变化とか粒 子成長を定量的に考察する場合には，まずこれらの過程 を支配している速度則を確立しておかなければならな い. 


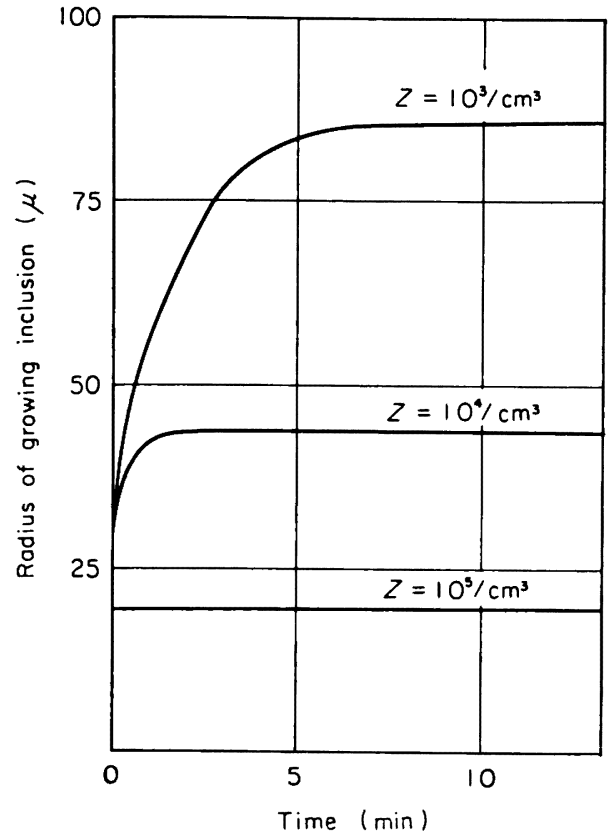

Fig. 3. Effect of number of nuclei on the rate of growth. $C_{0}=0.05 \% C_{e}=\mathrm{O}$ (E. T. Turkdogan).

一般的には二つの対立した見方がある.

1) 溶質原子の拡散によつて律速される.

反応界面では local equilibrium が成立している.

2）界面反応によつて律速される.

反応界面で local equilibrium は成立していない.

溶質原子の拡散によつて律速される場合の粒子成長速 度は, TURKDOGan が HaM の式を利用して計算してい るが3), 初酸素濃度 $0.05 \%$, 平衡酸素濃度 Oとしたと き Fig. 3 のような結果がえられている. 図から明らか なように, 成長速度は単位体積中に含まれる粒子数 $Z$ に よつて著しい影響をうけ, $Z=10^{5} / \mathrm{cm}^{3}$ の場合にはたか

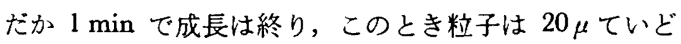
の大きさになる. ところが Photo. 1 あるいは Photo. 2 では $5 \mathrm{~min}$ 間も成長が続いており，しかも最終的な粒 子径から判断して，粒子数が少なくとも $10^{5} / \mathrm{cm}^{3}$ 以上 あることは確実なことから，B実験における $\mathrm{SiO}_{2}$ 粒子 の成長は，拡散律速的ではないと断定してよかろう.

そこでつぎ界面反応によつて律速される場合を検討 するわけであるが，この問題は結局 $\mathrm{Si}$ 脱酸反応機構の 解明と，その速度式を確立することに帰着する.

しかしながら脱酸過程をまともに研究対象とした場合 には，溶鉄中に存在する脱酸生成物の量とか分布状態あ
るいは反応界面積など見積もりのきわめて困難な因子が 多いために，実験結果から反応機構を解析することはほ とえど不可能といつてよい，このためには，まつたく異 なつた観点から実験方法を考案することが必要となる。

\section{4 溶鉄中への $\mathrm{SiO}_{2}$ の溶解反応 ${ }^{4}$}

実験的には， $\mathrm{C}$ 実験で $\mathrm{SiO}_{2}$ の溶鉄中への溶解反応を 研究することにした，すなわち $1550^{\circ} \mathrm{C}$ で平衡状態にあ る $\mathrm{SiO}_{2}$ 坩堝中の溶鉄温度を, $1600^{\circ} \mathrm{C}$ また $1635^{\circ} \mathrm{C}$ に急激に昇温し，これらの温度における平衡への移行過 程を追求する方法である. その理由としては，1）平衡 に到達するまでの全過程を扱かうので，この過程が化学 反応律速的と結論できれば，少なくとも高周被加熱下の 㩭拌浴においては，反応界面で local equilibrium の成 立していないことが確立されることになる．また，2) 溶鉄の $\mathrm{Si}$, 酸素変化は, $\mathrm{Si}$ 脱酸反応の寄与も含め可逆 反応形式でとりあつかうことになり，実験結果から $\mathrm{SiO}_{2}$ 溶解反応と同時に $\mathrm{Si}$ 脱酸反応の機構も考察することが できる.さらに 3) 本実験では脱酸過程に付随するよう な複雑な因子は介入してこないなどがあげられる。

Fig. 4 に $1635^{\circ} \mathrm{C}$ に昇温以後の溶鉄酸素变化を示し たが，定常拡散式によつてデータを整理した結果は，Si 濃度によつてそれぞれ異なる曲線となり，拡散律速の過 程と考えられないことが明らかとなつた。

そこで化学反応律速の立場から考察するわけである が Fig. 4 の結果から酸素增加の初速度と初酸素濃度の 関係をプロットすると，Fig. 5 のような関係がえられ， これらの曲線の形が吸着等温線のそれにきわめて類似し ていることから，界面に吸着した酸素が reactantとし て直接反応に関与していると考え, 種々検討した結果, $\mathrm{SiO}_{2}$ 溶解反応および $\mathrm{Si}$ 脱酸反応の進行を表わす overall の反応式として,

$$
\mathrm{SiO}_{2}+\mathrm{O}(\mathrm{ads})=\underline{\mathrm{Si}}+2 \underline{\mathrm{O}}+\mathrm{O}(\mathrm{ads})
$$

を採用した・酸素増加の速度式は，

$$
\begin{aligned}
d C_{\mathrm{O}} / d t & =\frac{2 F}{V}\left(k_{1} C_{\mathrm{O}(\mathrm{ads})}-k_{-1} C_{\mathrm{Si}} C_{\mathrm{O}}^{2} C_{\mathrm{O}(\mathrm{ads})}\right) \\
& =\frac{2 F}{V} \theta_{0} L k_{-1}\left(K_{\mathrm{S} 1}^{\prime}-C_{\mathrm{Si}} C_{\mathrm{O}}{ }^{2}\right) \cdots \cdots \cdots(
\end{aligned}
$$

ここで $\theta_{0}:$ 酸素の界面皮覆率,

$L$ : 界面における酸素の飽和吸着量

$k_{1}, k_{-1}: \mathrm{SiO}_{2}$ 溶解反応, $\mathrm{Si}$ 脱酸反応の見かけ の速度定数

Fig. 5 の関係から推定した吸着等温式を(2)式に代入 して計算した酸素曲線は, 実験結果ときわめてよく一致 し, $\mathrm{SiO}_{2}$ 溶解反応は平衝到達までの全過程が (1) 式に よつて律速されることを明らかにした．このことは，す 


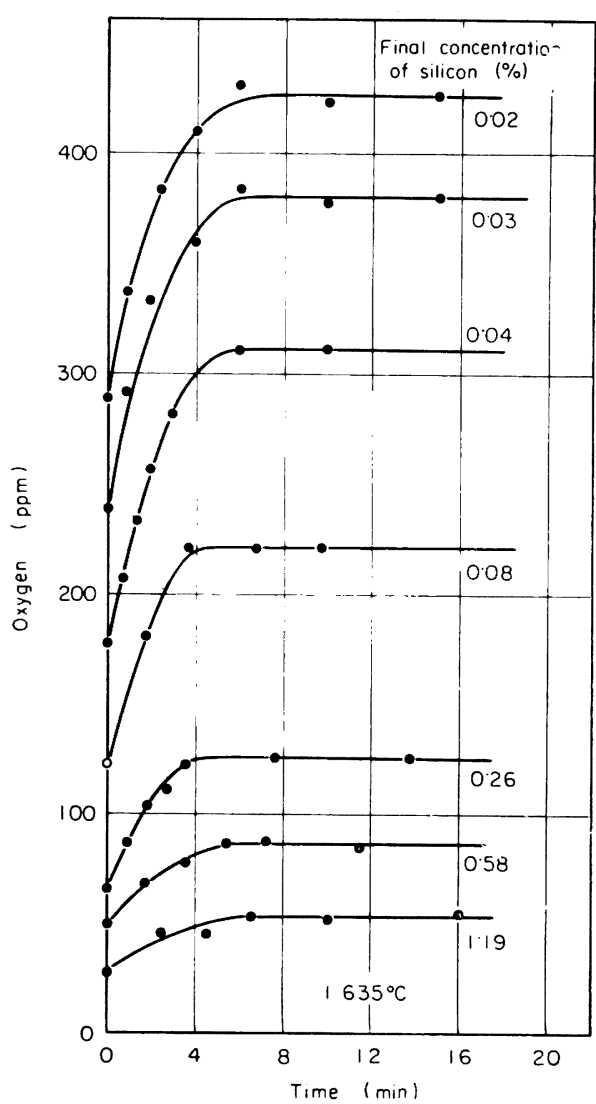

Fig. 4. Change of oxygen concentration in liquid iron with time, after the temperature being rapidly raised to $1635^{\circ} \mathrm{C}$ from $1550^{\circ} \mathrm{C}$.

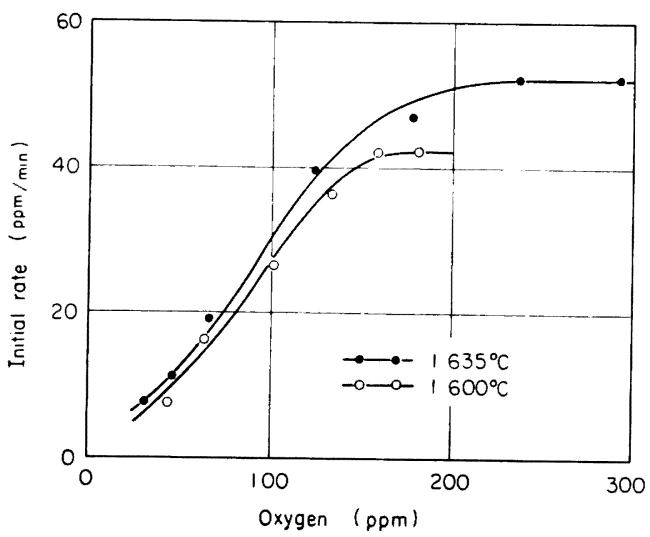

Fig. 5. Variation of the initial rate of oxygen increase with the initial concentration of oxygen.

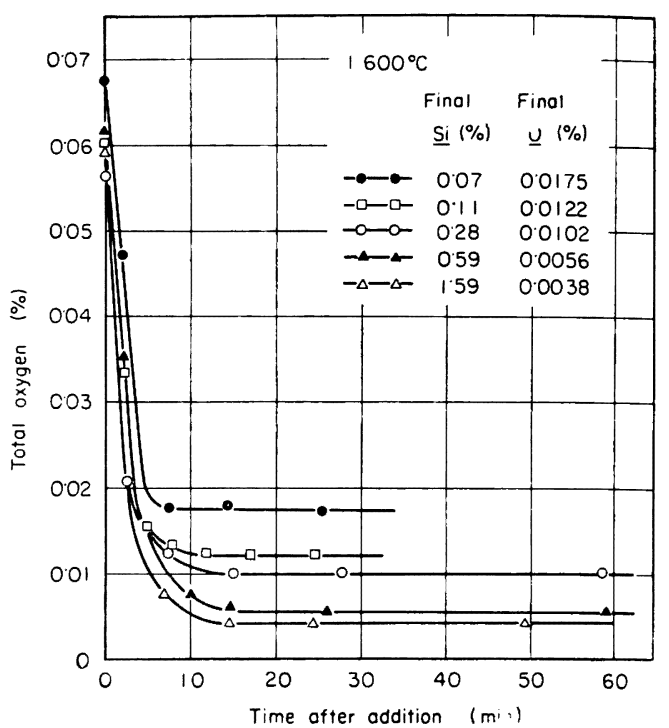

Fig. 6. Change of total oxygen of liquid iron with time after addition of various amount of $\mathrm{Si}$ at $1600^{\circ} \mathrm{C}$

でに述べたように，Si 脱酸反応の進行時反応界面で local equilibrium の成立してないことを意味している.

このようにして，B実験の粒子成長が界面反応によつ て律速されることを確認し，また反応機構と速度式を確 立した。

$\mathrm{Si}$ 脱酸反応の進行は, $\mathrm{Si}+2 \underline{\mathrm{O}}=\mathrm{SiO}_{2}$ のような単純 な化学方程式によつて表わすことができず，反応式に吸 着酸素が含まれていることは, 反応機構上きわめて注目 すべき点と考えられるが，このことはまた吸着酸素が反 応の進行にかぎらず，その他種々の脱酸現象に決定的影 響を及ぼす可能性のあることを暗示している.

\section{$3.5 \mathrm{Si}$ 脱酸過程}

前節までの 結果によつて, $\mathrm{Si}$ 脱酸の内容が漸次明り ようになつてきたが, 脱酸過程の定量的考察には,なお 末解决の問題が残されている. そのうちもつとも重要な ものは，核生成と脱酸生成物の浮上分離の挙動であ万 5 .

以下A実験の脱酸過程を例にとつて，これらの問題に 触れてみる。

Fig. 6 は $1600^{\circ} \mathrm{C}$ に保持した $\mathrm{SiO}_{2}$ 坩堝の溶鉄を $\mathrm{Si}$ 脱 酸したときの酸素変化を示した.平衡酸素值が〜 $120 \mathrm{ppm}$ 以下の場合は，Si 濃度によらずいずれも平衡到達にや く $15 \mathrm{~min}$ を要するが, $120 \mathrm{ppm}$ 以上の場合には, より 短時間に平衡に到達するのが特徴的である. また Fig. 7 は $1660^{\circ} \mathrm{C}$ に保持してから温度を下げ， $1600^{\circ} \mathrm{C}$ に保 


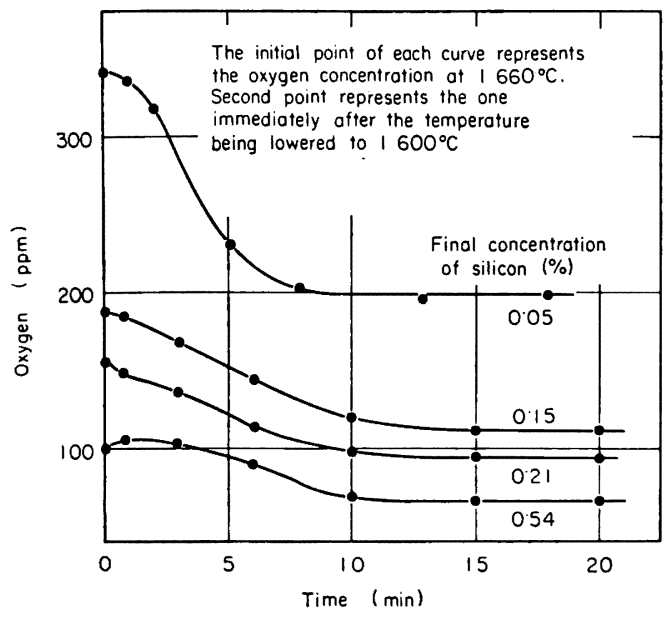

Fig. 7. The progress of the deoxidation after the temperature of the melt being lowered from $1660^{\circ} \mathrm{C}$ to $1600^{\circ} \mathrm{C}$.

持したときの脱酸過程を示したが，平衡到達時間につい ては，まつたく同様の特徴が認められた.なお Si 0.54 $\%$ ，初酸素濃度 $0.01 \%$ の場合には，核生成のための incubation 期間があり，この期間中脱酸の進行しない 様子が示されている.

平衡酸素値が $120 \mathrm{ppm}$ 以上の場合, 寸みやかに平衡 に到達するという事実は, 酸素濃度の高いとき $\mathrm{SiO}_{2}$ 粒 子が系外に分離しゃすいことを理由の一つにあげること ができるが，これを説明することは容易でない.

たとえば脱酸後の $\mathrm{SiO}_{2}$ 粒子の粒子径分布は, $\mathrm{Si}$ 添 加量に無関係にほほ同一の变化をしており，このような 場合とくに粒子の成長が容易で大粒子になりやすいとい うことはなかつた。

おそらく界面の性質が影響しているものと思われる がこここで注目しなければならないのは，さきに述べた ように, 吸着酸素の挙動であろう. 次報では4)吸着等温 線の形から, 吸着酸素間に引力の働くことを示唆した が, 酸素浱度の高いとき, 坩堝内壁と $\mathrm{SiO}_{2}$ 粒子間につ よい引力の作用するようなことがあれば，この事実を説 明することは可能なことを指摘したい.

またA実験でも $\mathrm{Si}, \mathrm{Si}-\mathrm{Mn}$ 脱酸後の生成物は大半が 球形であり，さらに Si-Mn 脱酸の場合には，B実験の ときと同様粒子の中心部に球形の別相が 1 個存在してい た.このことは，A実験のような攪拌浴においても，粒 子の衝突，凝集はほとんど起こつておらず，粒子の成長 はもつぱら拡散成長によることを物語つている.

すなわちA実験の場合にも, 脱酸後の相当時間酸素が

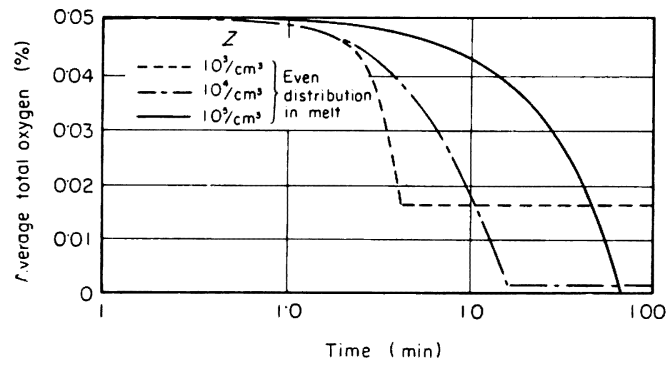

Fig. 8. Effect of number of nuclei and holding time on average total oxygen in liquid iron (E. T. TURKDOGEN).

過飽和に溶解していることは明らかであり，Fig. 6, 7 の脱酸過程を考察するさいには, 生成粒子の浮上分離の 問題以外に, 溶解酸素の挙動も同時に考虑することが必 要である.

これについては，溶解酸素がどこで消費されるかとい う問題がある.もし $\mathrm{Si}$ 脱酸反応が溶鉄中の $\mathrm{SiO}_{2}$ 粒子 の界面でのみ進行すると考えると，浴の鄮拌状況などに よつて, 粒子の分離が速やかな場合には, TURKDOGAN や SCHENCK $^{5}$ ) らの指摘しているように (Fig. 8), 過飽 和のまま溶解酸素の低下しえない状態がしばしば実現す ることになる. しかしながら $\mathrm{SiO}_{2}$ 坩堝中の溶鉄を $\mathrm{Si}$ 脱酸したときには，つねに $K^{\prime}{ }_{\mathrm{Si}}=[\% \mathrm{Si}][\% \mathrm{O}]^{2}$ を満足 する平衡状態に到達しており，過飽和な状態のえられる ことは皆無であつた.

このことは，脱酸反応の進行する場所がまだほかにも あることを暗示しており, 泉田の指摘した坩堝内壁にお ける反応進行を認めなければならない必然性があると考 えられる6).

現在 $\mathrm{Si}$ 脱酸後の溶解酸素変化を測定中であり, これ が明らかとなれば，上記の問題点に関する認識はさらに 深まるものと期待される.

つぎは核生成の問題であるが, 脱酸反応の進行状況を 左右するきわめて重大な過程であるにもかかわらず, 現 在これに関する知識はきわめて貧困である.

脱酸剤を投入し, 攪找するような場合には, 添加時に 脱酸元素の 濃度の高い領域が一時的にできるはずであ り，ここで核生成は容易に行なわれると考えられる. Si 添加量に無関係に 脱酸の進行することを示した Fig. 6 の結果は，これを裹付けている.しかしながらこのこと は脱酸反応の進行を論ずるとき, 核生成過程を無視して よいということではない。

たとえば Fig. 7 Si 0.54\% の脱酸経過は，核生成過 程の及ぼす影晁の興味ある一面を示しているといえよ 
う. VOLMER らによると, 球形粒子の核生成速度 $I$ は次 式で表わされるがて,

$$
\begin{aligned}
& I=\mathrm{A} \exp \left\{-\left(\Delta G^{*}+\Delta G_{\mathrm{A}}\right) / k T\right\} \\
& J G^{*}=\frac{16-\sigma^{3} v^{2}}{3\left(\Delta G_{V}\right)^{2}} \ldots \ldots \ldots \ldots \ldots \ldots \ldots \ldots \ldots \ldots \ldots \ldots \ldots
\end{aligned}
$$

$J G^{*}$ : 臨界核生成に要する自由エネルギー变化

$\sigma$ : 界面エネルギー $v$ : 酸化物分子容

$J G_{\mathrm{A}}$ : 溶質原子の拡散の活性化エネルギー

Fig. 7 では脱酸条件として与えた過飽和度 $\Delta \widehat{G}_{V}$ は, Si 濃度に無関係にすべて一定なので，結局 Si 0.54\%， 初酸素濃度 $100 \mathrm{ppm}$ の場合には， $\sigma$ が大きく，結果と

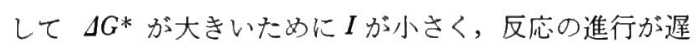
いと解される.

核生成過程によつて反応の開始が遅くなる場合の酸素 濃度が〜100 ppm 以下であるという事実と, 平衡酸素濃 度が同じく〜 $120 \mathrm{ppm}$ 以下のときに平衡到達に長時間を 要するという事実の間には, 本質的なつながりがあると 考えられ, 反応の進行を核生成と成長という観点からみ たとき, 脱酸過程にはなお開拓の余地のあるきわめて興 味ある問題が残されているように思われる.

\section{6 凝固過程における介在物生成}

凝固過程における介在物生成は, 凝固温度に打ける脱 酸反応の進行とみなされるが，とくに凝固過程において は, 種々の要因によつて過飽和度の形成状況が異なり, そのため核生成と成長の挙動は一層複雑となる. しかし ながら，われわれの観察する介在物は凝固試料中のもの でありこれが凝固過程中にどのように变化したか, あ るいはどのようにして生成し, 成長したかを適確に把握 することは, 脱酸現象の理解のために不可欠といえる.

ここではA実験の平衡状態から採取した水冷試料中の 介在物の観察結果を説明し，もつとも単純化した条件下 の介在物生成を論じてみよう。なお以下に述べる観察事 実は，その後報告された ELLIOTT らによる調査結果 ${ }^{87}$ とほとんど同一である.

平衡状態から析出した介在物には, 大きさおよび形態 からつぎの 3 種のものが認められた.

1) $\mathrm{Si}$ 濃度によつて大きさの決まるほぼ一様な粒径 の球形粒子, $\mathrm{Si}$ 濃度の高いとき粒子径は小さい.

(Photo. 3 )

2) Si 濃度に無関係な $0.5 \mu$ 以下の微粒子.

3) 樹枝状介在物, Si 浱度の高いとき, 量は少なく, 形も小さい.

一方 $\mathrm{Si}$, 酸素を含む溶鉄を水冷したときの $\mathrm{SiO}_{2}$ の核 生成には, 同様に 3 種の機構が考えられる.

a ) 凝固開始温度まで温度が降下する間に過飽和度が

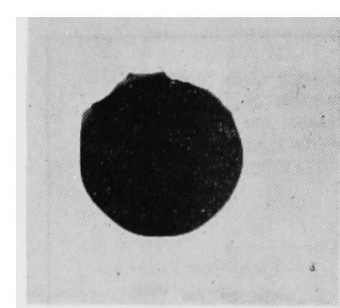

Si $0.07 \%$

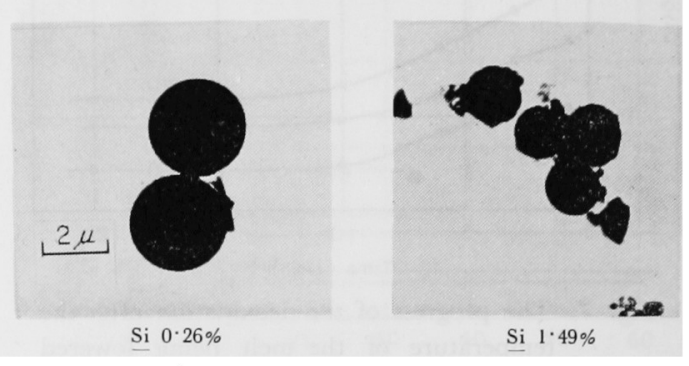

Photo. 3. $\mathrm{SiO}_{2}$ particles in the specimen when it was rapidly cooled into water from equilibrium state.
形成され，核生成する.

b ) 凝固前面に形成された過飽和度によつて核生成す る.

c）デンドライト樹間に溶質原子が濃化し，核生成す る.

これら 3 者のなかで成長時間のもつとも長いものは, a) で生成した介在物であり， b) で生成した介在物汢 ただちに凝固相に補促されるので, 成長時間はもつとも 短い.

前記 1)，7)，3）の3 種の介在物のなかでは，1）の 球形粒子がもつとも長洔間成長を続けたとみられること からこれらの粒子は、）の機構によつて生成したもの と考えてよい：また 2) の微粒子がb) の機構によつて 生成したことは明らかであり，この場合成長時間が短い ので，粒子径が $\mathrm{Si}$ 濃度や冷却条件などによつて影響さ れることも少ない：このように a )，b）による介在物 の生成, 成長に消費される $\mathrm{Si}$, 酸素の減少速度が遅く, デンドラィト樹間に溶質が濃化されてくれば, やがて c）の機構によつて核生成が起こる. 樹枝状介在物は樹 間濃縮部で新たに核生成した粒子あるいはすでに存在し ている粒子が成長するとき，樹間の間腙がせばまつてお り，また過飽和度も高いため，radial な方向に成長过 ず，間隙に沿つた形態をとつたものと考えられる.

いま 1) の球形粒子に着目すると, その平均粒子直径 は Si 0.07\% ではやく $2 \mu$, Si 0.6\% の場合にはやく $1 \mu$ で, 粒子 1 個の体積は前者がやく 8 倍も大きい. し 
かも樹枝状介在物は $0.07 \%$ のときに多量存在している から，この粒子径の变化は平衡酸素濃度の差だけに起因 するものではない. 粒子数の大小とも関係があり, $\mathrm{Si}$ $0.07 \%$ の場合には， a ）の核生成過程でより小数の核 しか生成されなかつたことが明白である.

(3)，（4)式によると，これは $\Delta G^{*}$ が大きく核生成 速度が小さいからであるが，Fig. 7 に関する核生成過程 の考察結果から, Si $0.07 \%$ (平衡酸素值〜 $180 \mathrm{ppm}$ ) の 場合 $\sigma$ は小さいと考えられるので, $\Delta G^{*}$ が大きいこと は結局, 凝固温度までの冷却過程中小さな過飽和度 $\Delta G_{V}$ の形成によつて，つまり冷却過程の初期に核生成したこ とを意味している.

また樹枝状介在物が生成するのは, 残液中の酸素の減 少速度すなわち $\mathrm{Si}$ 脱酸の速度が小さいからであるが, この理由については，すでに $3 \cdot 1$ 節で述べたとおりであ る. ElLIOTT らも凝固過程では溶鉄中の $\mathrm{Si}$, 酸素間に 平衡関係の成立してないことを確認し, 同様に $\mathrm{Si}$ 脱酸 反応の進行の遅いことも指摘している8).

以上平衡状態から泠却した試料中の介在物観察から, その生成機構を考察した・一般的には, 脱酸時に生成し た 1 次介在物も存在しており，事情はさらに複雑となる が，いずれにしても凝固時の介在物生成には，脱酸過程 と同様, 核生成と成長の挙動が決定的な役割を果たして おり，またこのさい界面の性質が重要な影響を及ぼすこ とを説明した。

凝固における介在物成機構の解明は, 脱酸反応機構の 解明にただちにつながるわけであり，冷却過程を制御で きるような条件下で, 今後さらに堀り下げた研究の行な われることが望まれる.

\section{4. 結論}

種々の実験結果にもとついて, Si 脱酸反応機構およ び凝固時の介在物の生成機構を考察し, つぎのように結 論をえた。

1) Si 脱酸では，Si 添加後に溶解酸素が急激に平衡 值をで低下するようなことはない。酸素は相当時間過飽 和に溶解している.

2) 生成した $\mathrm{SiO}_{2}$ 粒子の凝集はほとえど起こらず, 粒子の成長は, もつぱら拡散成長による.

3）粒子の成長過程すなわち脱酸の進行は, 㩭找浴で は界面反応によつて律速される.

4) 界面反応の進行は次式によつて表わされる.

$$
\mathrm{SiO}_{2}+\mathrm{O}(\mathrm{ads})=\underline{\mathrm{Si}}+2 \underline{\mathrm{O}}+\mathrm{O}(\mathrm{ads})
$$

5） $\mathrm{Si}$ 脱酸過程は，生成した $\mathrm{SiO}_{2}$ の分離と過飽和 な溶解酸素の低下の両面から考察しなければならない.
6) 脱酸過程も凝固時の介在物生成も，ともに核生成 と成長の挙動によつて決定的な影響をうける.

終わりに種々ご指導を賜わりました東北大学金属材料 研究所音谷登平教授に感謝いたします.

\section{文献}

1) 坂上, 川崎, 鈴木, 佐藤：鉄と鋼，55（1969）, p. 550

2 ) $W . A$. Fischer and $M$. Wahlster: Arch. Eisenhüttenw., 28 (1957), p. 601

3) E. T. Turkdogan: JISI, 204 (1966), p. 914

4) 坂上, 笹井: 鉄と鋼 投稿中

5 ) $H$. Schenck, E. Steinmetz. and $K . K$. Mehta: Arch. Eisenhüttenw., 41 (1970), p. 131

6 ）泉田：鉄と鋼，52 (1966), p. 1834

7 ) J. H. Hollomon and D. Turnbull: Progress in Metal Physics, 4 (1953), p. 333

8 ) $G$. Forward and $J . F$. Elllott: Trans. AIME, 1 (1970), p. 2889

\section{討論}

【筫問】宮下芳雄*

(1) $\mathrm{SiO}_{2}$ 粒子の凝集性の否定

$\left\lceil\mathrm{SiO}_{2}\right.$ 粒子の球形一体化は容易に起こるものでない」 としているが, 石英が製鋼温度で容易に軟化し，形ない 状を变化しうることを考虑すると，こう簡単に否定でき ないと思う。

\section{【回答】}

Si 脱酸後の介在物は，脱酸後のいかなる時点でも， 大半が輪郭のきわめて明確な球形粒子であつた。もし粒 子が衝突，凝集によつて成長するとすると，いつでも球 形粒子であるということは，衝突したとき，きわめて容 易に，またすみやかに 2 個あるいは数個の粒子の球形一 体化が起こることを認めなければならない。

ところが，前報 B 実験で1)，Si 脱酸後サンプラーに振 動を与えると，漂篭形とか棈円形の $\mathrm{SiO}_{2}$ 介在物が著し く増加することを確認した。なぜにこれらの介在物は球 形にならなかつたのか. その他，衝突説にとつて具合の 悪い現象はいくつか報告したとおりである. Photo. 2 が 核生成一成長機楧による粒子成長を示していることは, 素直に眺めれば理解できるのではないか.

【質問】介在物成長の搪散律速の否定

根拠として，B 実験の粒子成長が Fig. 3 の $Z=10^{5}$ / $\mathrm{cm}^{3}$ の曲線に一致しないことをあげておられるが, TURKDOGAN の結果は非常に限られた条件のもとに得ら れており，これと一致しないからといつて搪散律速ての ものを否定することは行きすぎだと思う。

\section{【回答】}

B実験の条件下では，TURKDOGAN の計算の前提にな つている、核の均一分散をまず满足していると考えられ る. その理由としては， Si が少なくとも $1 \mathrm{sec}$ 以内に は均一溶解することと, 成長粒子の大きさがほぼ均一な ことがあげられる.

さて実際の粒子成長速度は, 㧓散律速として計算した ものより，はるかに遅い。拡散律速を否定する以外にな 
いと思う。このことは， $\mathrm{SiO}_{2}$ 溶解反応の速度論的研究 から (次盛, 本誌 1971 年 14 号), $\mathrm{SiO}_{2}$-溶鉄界面で local equilibrium は成立していないという形で証明さ れた。

\section{【質問】}

Fig. 4 の結果が拡散律速で説明できないこと

理由を説明下さるようお願いします。酸素が一定值に 到達する時期が各ヒートで一致していることから，むし ろ拡散方程式でうまく説明されると思う。

\section{【回答】}

Fig. 4 の結果の平衡到達時間は, $\mathrm{Si}>0.58 \%$ の場合 $6 \mathrm{~min}, 0.26 \%, 0.08 \%$ が $4 \mathrm{~min},<0.04 \%$ の場合 $6 \mathrm{~min}$ である。この結果が拡散律速で説明できないと述べた理 由は，拡散方程式によつて説明できなかつたからであ る.

\section{【質問】}

Fig. 5 の説明に $\mathrm{O}(\mathrm{ads})$ を尊入したこと

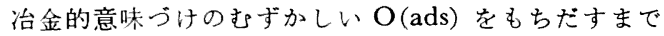
もないと思う。 O (ads) は粒子の成長にしたがい変化す る量なのであろうか.

\section{【回答】}

治金的意味うけのむすかしいO $\mathrm{O}(\mathrm{ads})$ とあるが，反応 界面には，つ权に吸着酸素が存在することを考慮すべき ではないか，界面における酸素のやりとりの反応である 脱酸反応の進行に, そこに存在する吸着酸素が治金的意 味をもたないとは考えられない。

\section{【質問】}

Fig. 5 と(2) 式の一致について

吸着等温式の内容がよくわからないが，Fig. 5 の結果 を(2)式に代入して得られた計算曲線が Fig. 4 の結果 ときわめてよい一致を示すことは当然のように思元る.

\section{【回答】}

Fig. 5 の結果から推定した吸着等温式を(2)式に代入 したことは，酸素曲線の打ち出し角度を与兄たことにな るが，それ以後の酸素変化とか到達時間を与えてはいな い.よい一致を示すのは当然というのは当たらない。

\section{【倎問】}

Fig. 6 における平衡到達時問

$\mathrm{O}=120 \mathrm{ppm}$ の上下で, 到達時間に明らかな差がある ことを重視しているが，O > $120 \mathrm{ppm}$ は1 ヒートしか例 かなく，かかる実験の再現性の悪さを考虑すれば，あま り差がないと判断したほうがよいように思う。

\section{【回答】}

$\mathrm{O}=120 \mathrm{ppm}$ の上下で到達時間に差があるという現象 は，これまでの Si 脱酸， $\mathrm{Si}-\mathrm{Mn}$ 脱酸ではいつでも経䀦
している.この理由は，本交中にも述べたように，現在 まだ明らかではないが，Si 脱酸過程の本質にふれる問 題と考光る.

\section{【質問】る}

(8) Fig. 7, $\mathrm{Si}=0.54 \%$ の場合の解釈

$\mathrm{Si}=0.54$ と $\mathrm{Si}=0.21 \%$ とで，図に示されるような本 質的な差があるとは思えない，平衡值を信用すれば， $\mathrm{Si}$ 濃度が高くなるにしたがい，Oの温度变化量が小さく なる傾向は出てくるが，この場合もそのような傾向が現 われたものと考えられないだろうか。

\section{【回答】}

(8)酸素の温度变化量が小さくなるためとは考えられ ない、同種の実験を $\mathrm{Si}-\mathrm{Mn}$ 脱酸でも行なつているが, 初酸素濃度 < 100ppm の場合には, 同様に酸素の低下 しない潜伏期がある。

\section{【質問】}

Fig. 8 の解釈, 化学反忘進行の場所

過飽和のまま溶解酸素が低下しえないような状態はあ る仮定が成立しており，かつ $Z$ が小さい場合にのみあり うる貴研究においては，自らすでに記述しているよう $Z>10^{5} / \mathrm{cm}^{3}$ ですから, Fig. 8 からみてわかるように, 過飽和状態が起り得ないのは明白である.したがつて貴 実験で, 過飽和状態が起こりえないから, 脱酸反応進行 の場所が $\mathrm{SiO}_{2}$ 粒子界面以外にあるとするのはおかしい と思う.

\section{【回答】}

(9) 小生の $\mathrm{Si}$ 脱酸に関する研究は, $Z>10^{5} / \mathrm{cm}^{3}$ な のに，なぜ過飽和と見られるような脱酸現象が観察され るのかということから始まつているわけである.

なお, A 実験の $\mathrm{Si}$ 脱酸過程では, 酸素は過飽和に溶 解していることを現在確認している.

\section{【質問】}

\section{$\sigma$ と $I$ の関係}

$\sigma$ は $\mathrm{Si}$ の低い場合には变わる可能性があると思う が, $\mathrm{Si}=0 \cdot 21, \mathrm{Si}=0.54 \%$ のそれぞれでは酸素值もそれ ほど差がないし，自に大きな差が出てくるとは考えられ ない.したがつて， $\sigma$ から Fig. 7 の $\mathrm{Si}=0.54 \%$ の の挙動を説明するのはむずかしいと思う.このような実 験結果の再限性はあるのだろうか.

\section{【回答】}

Si $0.21 \%$ と $0.54 \%$ で $\sigma$ に大差があると考元られな いとあるが，たとえば HALDEN and KINGERYの求めた $\mathrm{Al}_{2} \mathrm{O}_{3}$-溶鉄の $\sigma$ は 0〜 $100 \mathrm{ppm}$ 以下になると, 急激に低 下している．Si 濃度に着目するよりも，酸素濃度に着 目すべきであろう。再現性はある. 